\title{
Interfacial Reactions of High-Bi Alloys on Various Substrates
}

\author{
JIN-YI WANG ${ }^{1}$ CHIH-MING CHEN, ${ }^{1,3,4}$ and YEE-WEN YEN ${ }^{2}$ \\ 1.-Department of Chemical Engineering, National Chung-Hsing University, Taichung 402, \\ Taiwan. 2.-Department of Materials Science \& Engineering, National Taiwan University of \\ Science \& Technology, Taipei, Taiwan. 3.-e-mail: chencm@dragon.nchu.edu.tw. 4.-e-mail: \\ chencm@nchu.edu.tw
}

\begin{abstract}
Bi-Sn alloys with high $\mathrm{Bi}$ concentration are potential candidates to replace high- $\mathrm{Pb}$ alloys as high-temperature $\mathrm{Pb}$-free solders. Interfacial reactions between high-Bi alloys (Sn concentration 2 wt.\%, 5 wt.\%, and 10 wt.\%) and various substrates have been investigated to understand the intermetallic compound formation and interfacial morphological evolution at the joint interface. The substrates investigated include $\mathrm{Ni}, \mathrm{Au} / \mathrm{Ni}, \mathrm{Cu}$, and $\mathrm{Ag} / \mathrm{Cu}$ layers deposited on Si chips. The interfacial reactions were carried out at $300^{\circ} \mathrm{C}$ and $120^{\circ} \mathrm{C}$ to simulate the liquid/solid and solid/solid reactions, respectively, at such solder joints. Experimental results reveal that the intermetallic compound formation and interfacial morphological evolution vary with the substrate and the Sn concentration of the Bi-Sn alloy.
\end{abstract}

Key words: Interfacial reaction, high-temperature solder, Bi, substrate

\section{INTRODUCTION}

$\mathrm{Pb}-\mathrm{Sn}$ alloys with $\mathrm{Pb}$ concentration higher than 95 wt. $\%$ possess higher melting points around $312^{\circ} \mathrm{C}$ to $327^{\circ} \mathrm{C}$ and can withstand multiple reflows in the packaging process, and so have long been used as high-temperature solders in high-end electronic packaging. ${ }^{1,2}$ Interfacial reactions accompanying intermetallic compound formation usually occur in solder joints during reflow and are taken as an indicator that joining of the solder joint is complete. ${ }^{3-6}$ However, excessive growth and irregular morphological evolution of intermetallic compounds may degrade the solder joint mechanically. ${ }^{7}$ Therefore, clear understanding of interfacial reactions is crucial for reliability evaluation of solder joints.

To address the global trend for bans on $\mathrm{Pb}$ in microelectronic products, efforts have been made to search for high-temperature $\mathrm{Pb}$-free alloys to replace high- $\mathrm{Pb}$ solders. Eutectic $\mathrm{Bi}-\mathrm{Ag}$ alloy (Bi-2.5 wt.\% Ag) is attractive because of its acceptable melting point $\left(262.5^{\circ} \mathrm{C}\right)$ and affordable cost. ${ }^{8}$ Increasing the $\mathrm{Ag}$ content to 11 wt.\% can improve the thermal conductivity and electrical resistivity of $\mathrm{Bi}-\mathrm{Ag}$ alloy for higher application performance. ${ }^{9,10}$

(Received February 17, 2013; accepted July 14, 2013; published online August 15, 2013)
It was found that no intermetallic compound was formed at the $\mathrm{Bi}-\mathrm{Ag} / \mathrm{Cu}$ interface after reflowing at $350^{\circ} \mathrm{C}$. Instead, grain boundary grooving of the $\mathrm{Cu}$ substrate by liquid $\mathrm{Bi}-\mathrm{Ag}$ penetration occurred, which provided mechanical bonding between the solder and substrate. ${ }^{8}$ By contrast, two intermetallic compounds, namely cellular-type $\mathrm{NiBi}_{3}$ and layertype $\mathrm{NiBi}$, were formed at the $\mathrm{Bi}-\mathrm{Ag} / \mathrm{Ni}$ interface. ${ }^{8}$ $\mathrm{Zn}-x \mathrm{Sn}$ alloys $(x=20 \mathrm{wt} . \%, 30 \mathrm{wt} . \%$, and $40 \mathrm{wt} . \%)$ are also potential candidate high-temperature solders. Two intermetallic compounds, i.e., $\mathrm{CuZn}_{5}$ and $\mathrm{Cu}_{5} \mathrm{Zn}_{8}$, were formed at the $\mathrm{Zn}-x \mathrm{Sn} / \mathrm{Cu}$ interface after soldering. ${ }^{11}$ Mechanical tests indicated that the shear strength of the $\mathrm{Zn}-x \mathrm{Sn} / \mathrm{Cu}$ joint was higher than that for $\mathrm{Pb}-5$ wt.\% Sn. It was also found that the thermal conductivity of the $\mathrm{Zn}-x \mathrm{Sn}$ alloys was higher than that of Pb-5 wt.\%Sn. For the Zn$x \mathrm{Sn} / \mathrm{Ni} \quad(x=20$ wt. $\%, \quad 30$ wt. $\%, 40$ wt. $\%, \quad$ and $50 \mathrm{wt} . \%)$ interfacial reactions at $380^{\circ} \mathrm{C}$ to $420^{\circ} \mathrm{C}$, only one intermetallic compound, namely $\mathrm{Ni}_{5} \mathrm{Zn}_{21}$, was formed at the interface. ${ }^{12}$ However, the growth behavior and microstructure of the $\mathrm{Ni}_{5} \mathrm{Zn}_{21}$ phase varied with the Sn content.

Bi-Sn alloys with high $\mathrm{Bi}$ content are other potential substitutes for high-Pb alloys. High-Bi alloy has a wide mushy zone, with liquidus temperature around $250^{\circ} \mathrm{C}$ but solidus temperature of 


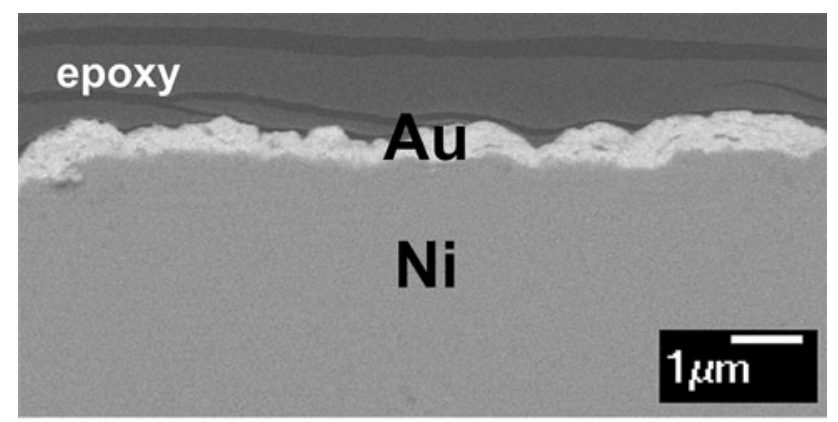

(a)

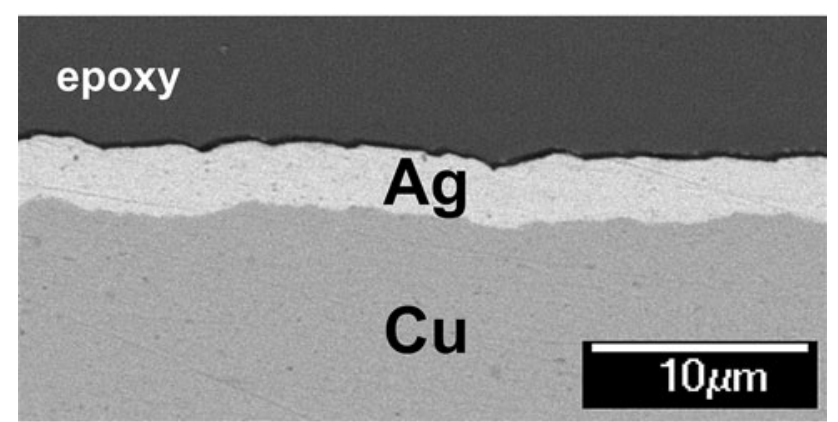

(b)

Fig. 1. Cross-sectional SEM micrographs of (a) $\mathrm{Ni}$ substrate deposited with an Au layer and (b) Cu substrate deposited with an $\mathrm{Ag}$ layer. only $138^{\circ} \mathrm{C} .{ }^{13}$ During soldering, the limited Sn in the high-Bi alloy is consumed quickly due to intermetallic compound formation, and accordingly the solidus temperature increases rapidly, enabling high-Bi alloys to withstand subsequent multiple reflows. When high-Bi alloys ( $\mathrm{Sn} \leq 10 \mathrm{wt} . \%$ ) were soldered with $\mathrm{Cu}$, only the $\mathrm{Cu}_{3} \mathrm{Sn}$ phase was formed at the interface when reacted at $300^{\circ} \mathrm{C}$ for $15 \mathrm{~s}$ to 90 min. ${ }^{14}$ The $\mathrm{Cu}_{3} \mathrm{Sn}$ phase was found to detach from the $\mathrm{Cu}$ substrate, and the gap between the $\mathrm{Cu}_{3} \mathrm{Sn}$ phase and the $\mathrm{Cu}$ substrate was filled by a (Bi) phase. Shear testing indicated that the high-Bi/ $\mathrm{Cu}$ joint was mechanically comparable to the high$\mathrm{Pb} / \mathrm{Cu}$ joint. To gain more information regarding the compatibility of high-Bi alloys with other substrates, the interfacial reactions between high-Bi alloys and other common substrates were investigated in this work. The common substrates investigated include $\mathrm{Ni}, \mathrm{Au} / \mathrm{Ni}$, and $\mathrm{Ag} / \mathrm{Cu}$.

\section{EXPERIMENTAL PROCEDURES}

Sn (99.9\% purity; Showa, Japan) and Bi (99.998\%; Alfa Aesar, USA) shots were used to prepare high-Bi alloys. Proper amounts of $\mathrm{Sn}$ and $\mathrm{Bi}$ shots were weighed and sealed in a vacuum quartz tube $\left(4 \times 10^{-3}\right.$ torr $)$. The sealed vacuum quartz tube was

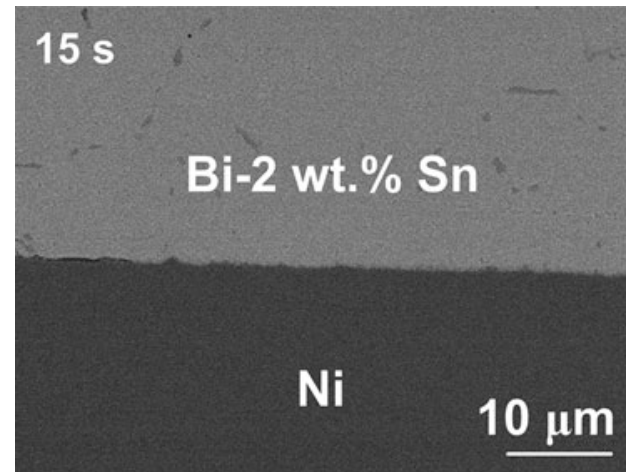

(a)

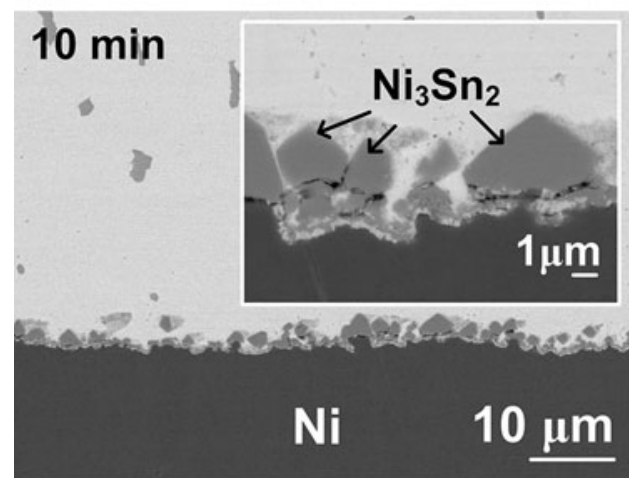

(c)

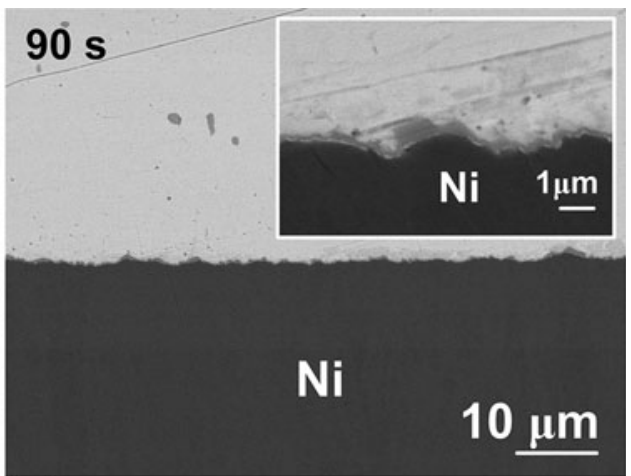

(b)

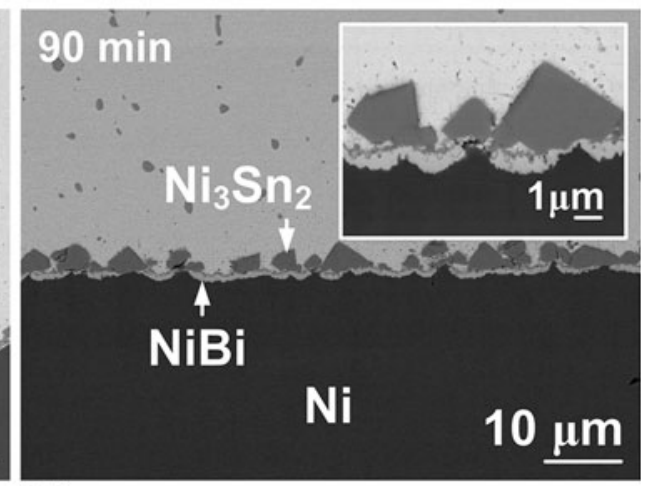

(d)

Fig. 2. SEM micrographs of $\mathrm{Bi}-2 \mathrm{wt} . \% \mathrm{Sn} / \mathrm{Ni}$ interfaces reacted at $300^{\circ} \mathrm{C}$ for (a) $15 \mathrm{~s}$, (b) $90 \mathrm{~s}$, (c) $10 \mathrm{~min}$, and (d) $90 \mathrm{~min}$. 


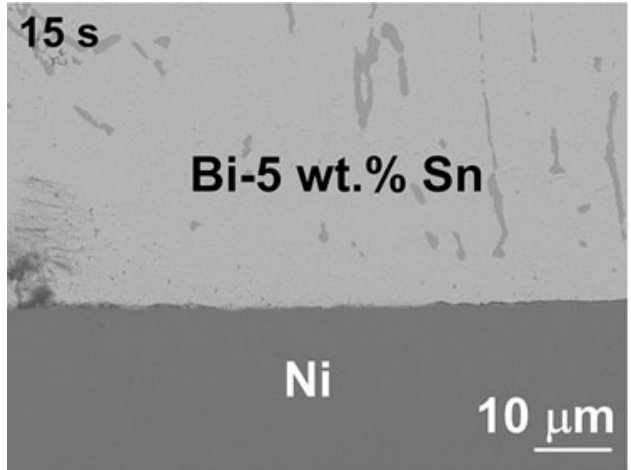

(a)

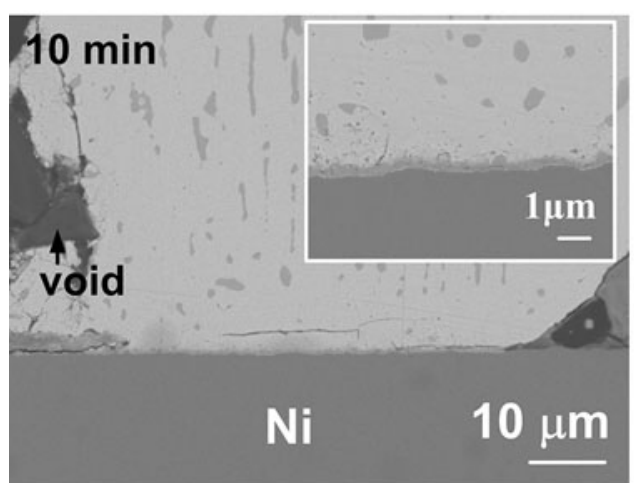

(c)

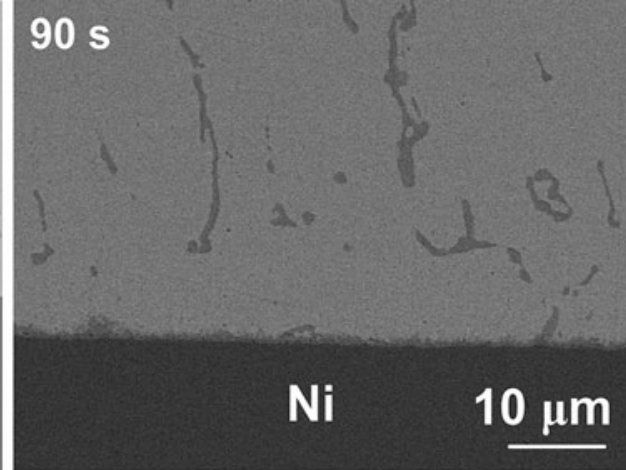

(b)

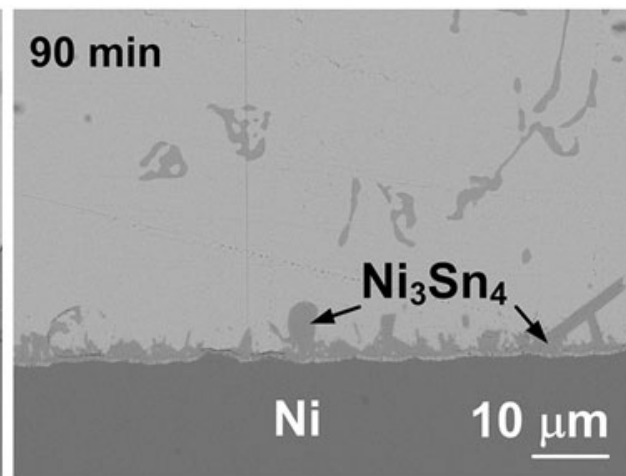

(d)

Fig. 3. SEM micrographs of Bi- $5 \mathrm{wt} \% \mathrm{Sn} / \mathrm{Ni}$ interfaces reacted at $300^{\circ} \mathrm{C}$ for (a) $15 \mathrm{~s}$, (b) $90 \mathrm{~s}$, (c) $10 \mathrm{~min}$, and (d) $90 \mathrm{~min}$.

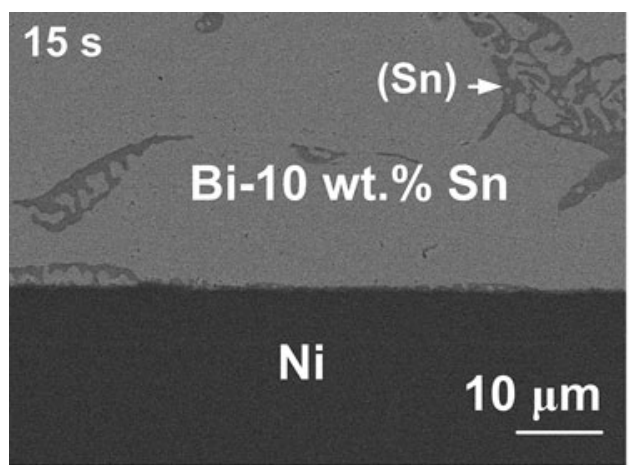

(a)

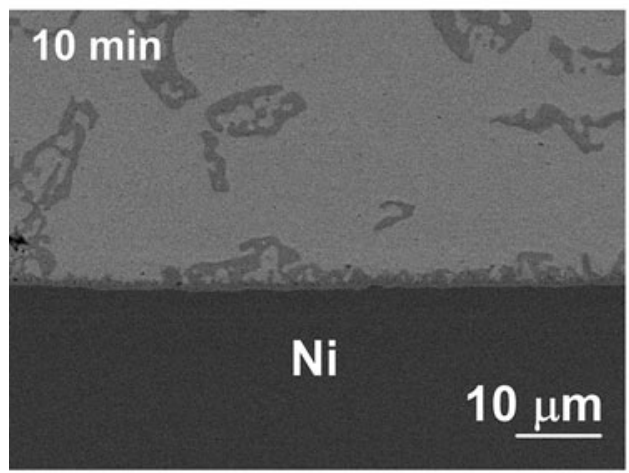

(c)

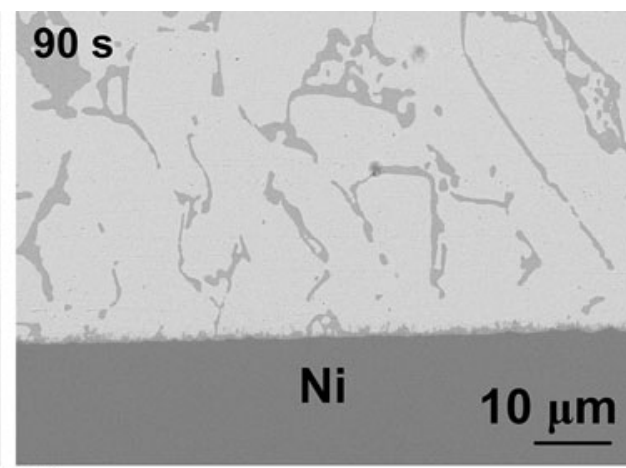

(b)

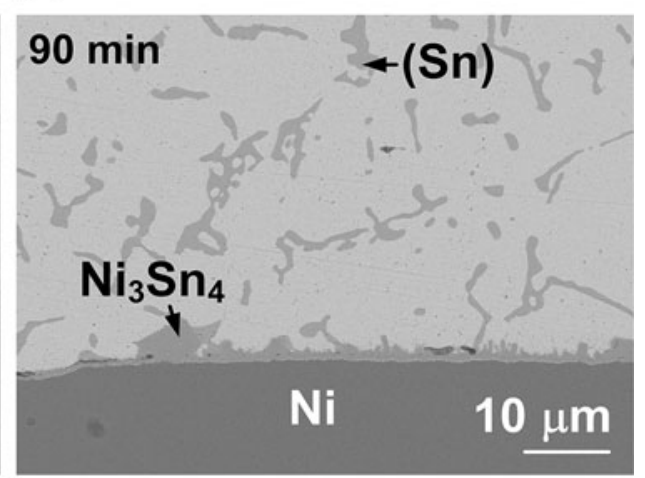

(d)

Fig. 4. SEM micrographs of $\mathrm{Bi}-10 \mathrm{wt} \% \mathrm{Sn} / \mathrm{Ni}$ interfaces reacted at $300^{\circ} \mathrm{C}$ for (a) $15 \mathrm{~s}$, (b) $90 \mathrm{~s}$, (c) $10 \mathrm{~min}$, and (d) $90 \mathrm{~min}$. 


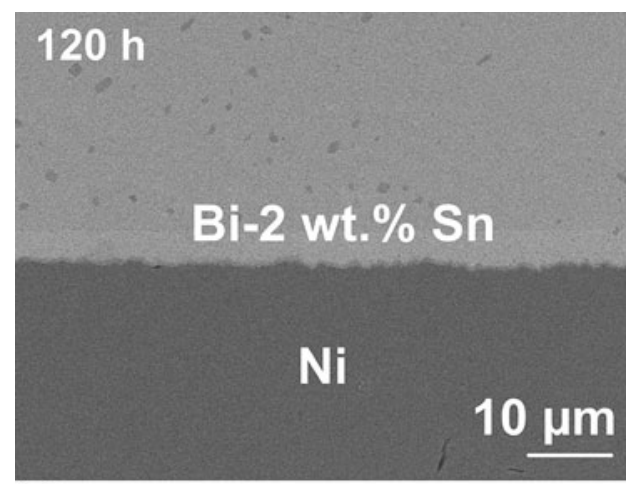

(a)

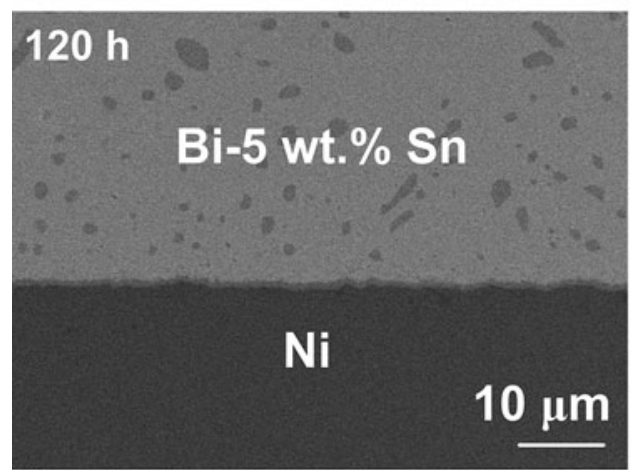

(c)

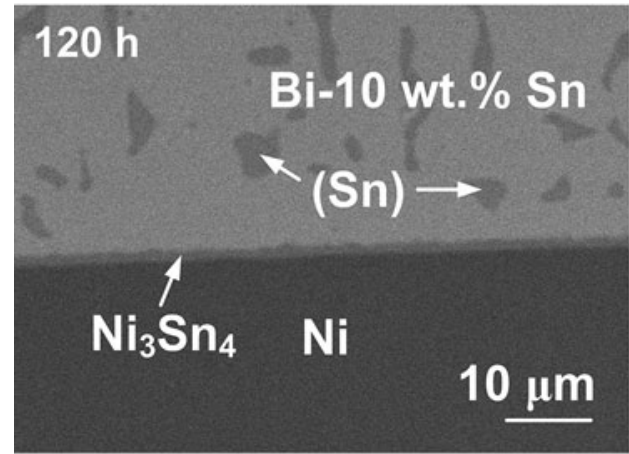

(e)

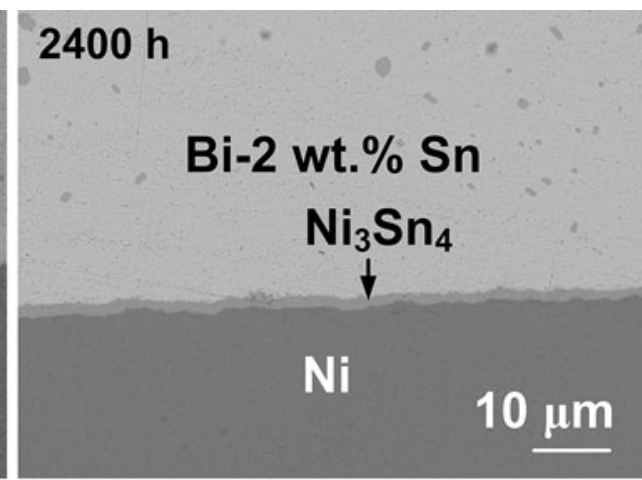

(b)

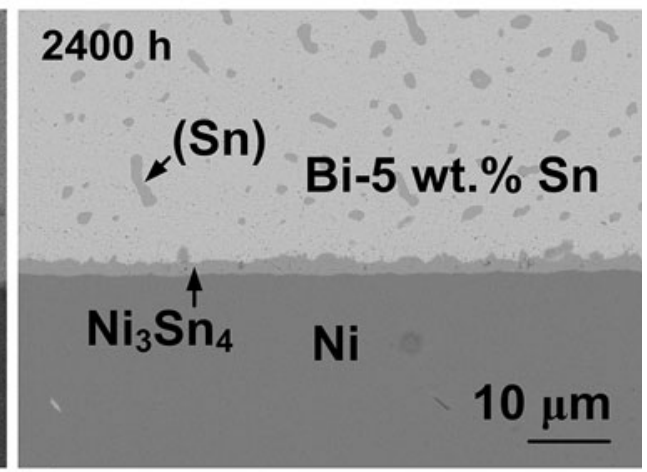

(d)

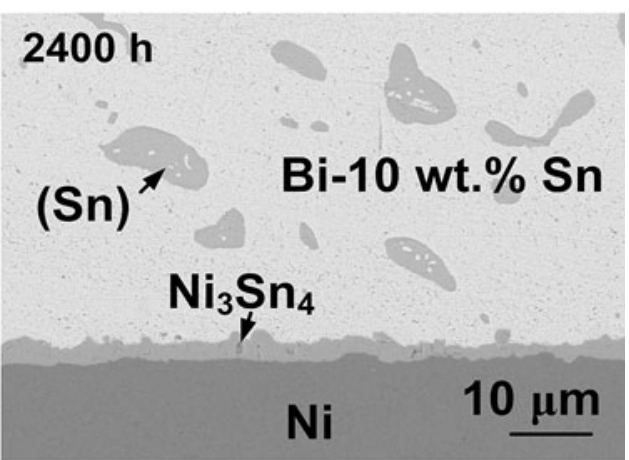

(f)

Fig. 5. SEM micrographs of high-Bi/Ni interfaces reacted at $120^{\circ} \mathrm{C}$ : (a) Bi-2 wt.\%Sn/Ni for $120 \mathrm{~h}$, (b) Bi-2 wt.\%Sn/Ni for $2400 \mathrm{~h}$, (c) Bi-5 wt.\%Sn/ $\mathrm{Ni}$ for $120 \mathrm{~h}$, (d) Bi-5 wt.\%Sn/Ni for $2400 \mathrm{~h}$, (e) Bi-10 wt.\%Sn/Ni for $120 \mathrm{~h}$, and (f) Bi-10 wt.\%Sn/Ni for $2400 \mathrm{~h}$.

put into a furnace at $900^{\circ} \mathrm{C}$, and the quartz tube was shaken periodically to enhance the homogeneity of the molten alloys during annealing. After $120 \mathrm{~h}$, the molten alloy was quenched in ice-water. Several pieces $(2.2 \mathrm{mg})$ of alloy were cut from the solidified ingot and were cleaned in $\mathrm{H}_{2} \mathrm{SO}_{4}(5 \%)$ solution for $3 \mathrm{~s}$ to remove surface oxides and contamination.

Four types of metallic layers, i.e., $\mathrm{Ni}, \mathrm{Au} / \mathrm{Ni}, \mathrm{Cu}$, and $\mathrm{Ag} / \mathrm{Cu}$, were deposited on Si chips as substrates. The first type of substrate was a $400-\mu$ m-thick Si chip (4 inch diameter) with a $25-\mu$ m-thick Ni layer deposited by electroplating at $0.6 \mathrm{~A}$ for $3 \mathrm{~h}$. Prior to $\mathrm{Ni}$ electroplating, a $0.4-\mu \mathrm{m}$-thick $\mathrm{Ni}$ layer was sputtered onto the Si chip to improve the adhesion between the subsequent electroplated $\mathrm{Ni}$ layer and the $\mathrm{Si}$. The second type of substrate was fabricated by depositing a thin Au layer on the first type of substrate using electroless plating. Electroless plating was conducted at $75^{\circ} \mathrm{C}$ to $85^{\circ} \mathrm{C}$, and the time was controlled to $15 \mathrm{~min}$, which produced a thin $\mathrm{Au}$ layer of about $0.7 \mu \mathrm{m}$, as shown in Fig. 1a. The third type of substrate was a $400-\mu$ m-thick Si chip with a deposited $\mathrm{Cu}$ layer. A 0.4- $\mu$ m-thick $\mathrm{Cu}$ layer was first deposited on the Si chip using sputtering and was thickened to $25 \mu \mathrm{m}$ using electroplating at $0.05 \mathrm{~A}$ for $3 \mathrm{~h}$. A 2.5- $\mu$ m-thick Ag layer was grown on the electroplated $\mathrm{Cu}$ layer using electroplating as the fourth type of substrate, as shown in Fig. 1b. Ag electroplating was carried out at $0.1 \mathrm{~A}$ for $3.5 \mathrm{~min}$. To control the joining area between the high-Bi alloy and the substrate, a solder mask with an open square window was coated on the substrate. The 


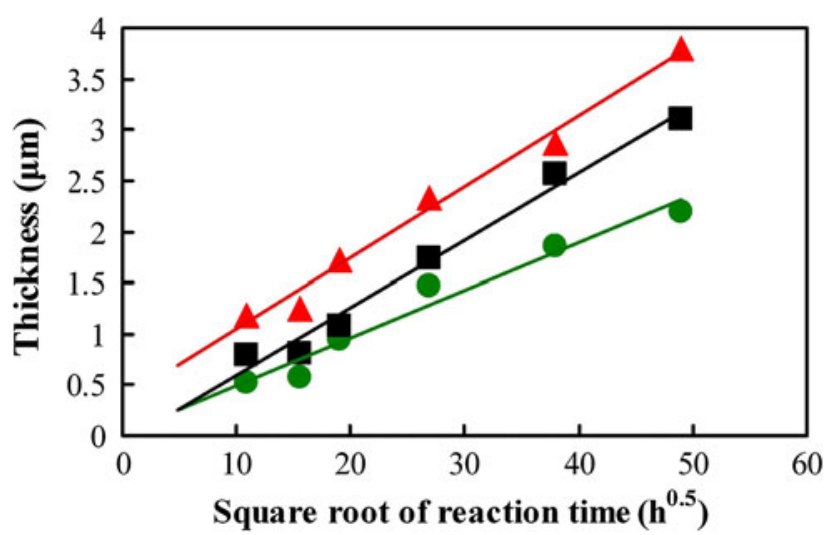

Fig. 6. Relationship between the thickness of $\mathrm{Ni}_{3} \mathrm{Sn}_{4}$ formed at the high-Bi/Ni interface reacted at $120^{\circ} \mathrm{C}$ and the square root of reaction time. $\boldsymbol{\Delta} \mathrm{Bi}-10$ wt. $\%$ Sn, $\boldsymbol{B i}-5$ wt. $\%$ Sn, $\bullet \mathrm{Bi}-2$ wt.\%Sn.

side length of the open square window was $600 \mu \mathrm{m}$. An alloy piece was coated with flux (Magana 51 flux, USA) and then placed on the uncovered surface of the substrate.

Two types of experiments were conducted to investigate the interfacial reactions of the high-Bi alloys on the various substrates. One was liquid/ solid reaction with reaction temperature of $300^{\circ} \mathrm{C}$, at which the high-Bi alloys were in liquid state. The other was solid/solid reaction at $120^{\circ} \mathrm{C}$, at which the high-Bi alloys were in solid state. In the former reaction, the samples were placed on a hot plate set at $300^{\circ} \mathrm{C}$. The high-Bi alloys melted rapidly and wetted the substrate. After reaction for $15 \mathrm{~s}$ to 90 min, the samples were removed from the hot plate and were mounted in epoxy resin for metallographic examination. The samples were ground and polished to expose cross-sections of the joint interface. Scanning electron microscopy (SEM) was used to observe the microstructure of the joint interface. Energy-dispersive x-ray (EDX) spectrometry was used for compositional analysis of the reaction products. For the solid/solid reaction, the samples were placed on a hot plate at $300^{\circ} \mathrm{C}$ for $90 \mathrm{~s}$ to accomplish joining between the high-Bi alloy and substrate. Then, the samples were placed in an oven at $120^{\circ} \mathrm{C}$ for various lengths of time. After reaction, the high-Bi/substrate interfaces were examined metallographically as described above.

\section{RESULTS AND DISCUSSION}

\section{High-Bi/Ni Interfacial Reactions}

Figure 2 shows SEM micrographs of Bi-2 wt.\% $\mathrm{Sn} /$ $\mathrm{Ni}$ interfaces reacted at $300^{\circ} \mathrm{C}$ for $15 \mathrm{~s}$ to $90 \mathrm{~min}$. No noticeable intermetallic compound was found at the interface after reaction for $15 \mathrm{~s}$, as seen in Fig. 2a. A new phase layer was formed at the interface after $90 \mathrm{~s}$, as seen in Fig. 2b, although it was too thin (less than $0.5 \mu \mathrm{m}$ ) to conduct compositional analysis using SEM-EDX. After reaction for $10 \mathrm{~min}$, as seen in Fig. 2c, an island-type phase was found at the

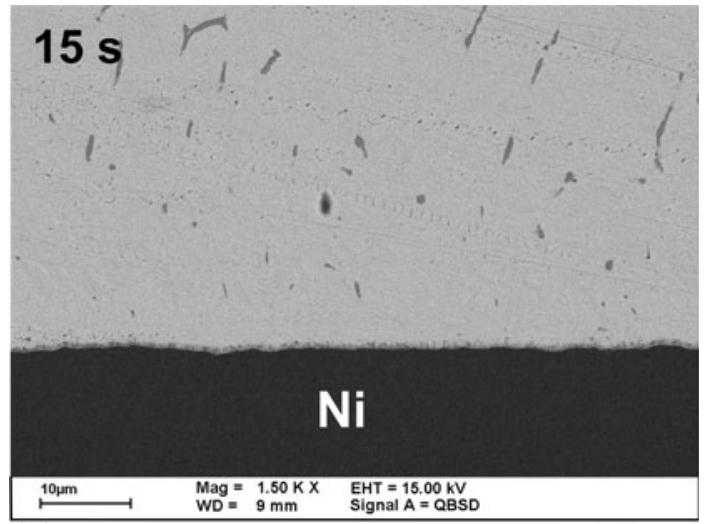

(a)

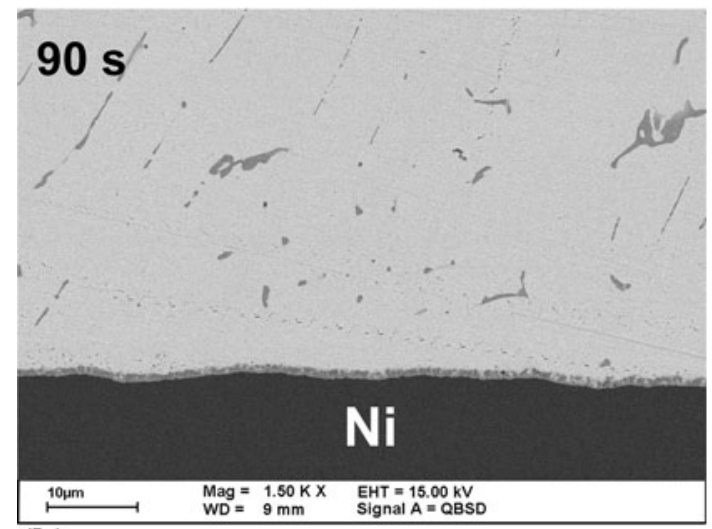

(b)

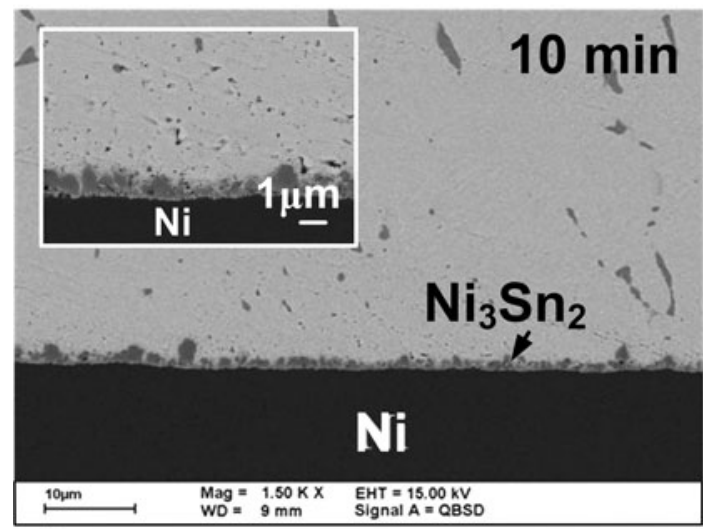

(c)

Fig. 7. SEM micrographs of Bi-2 wt. $\% \mathrm{Sn} / \mathrm{Au} / \mathrm{Ni}$ interfaces reacted at $300^{\circ} \mathrm{C}$ for (a) $15 \mathrm{~s}$, (b) $90 \mathrm{~s}$, and (c) $10 \mathrm{~min}$.

interface. Compositional analysis indicated that this phase contained 56.2 at. $\% \mathrm{Ni}-42.5$ at.\% $\%$ 1.3 at. $\% \mathrm{Bi}$, identified as the $\mathrm{Ni}_{3} \mathrm{Sn}_{2}$ phase. After reaction for $90 \mathrm{~min}$, another new phase layer was found at the $\mathrm{Ni}_{3} \mathrm{Sn}_{2} / \mathrm{Ni}$ interface, as seen in Fig. $2 \mathrm{~d}$. According to the result of compositional analysis (49.2 at.\% $\mathrm{Ni}-46.7$ at.\%Bi-4.1 at.\%Sn), this new phase was identified as the $\mathrm{NiBi}$ phase with a small amount of dissolved Sn.

When the Sn content was increased to 5 wt.\%, intermetallic compound was hardly formed until 10 min of reaction, as seen in Fig. 3c. The intermetallic 


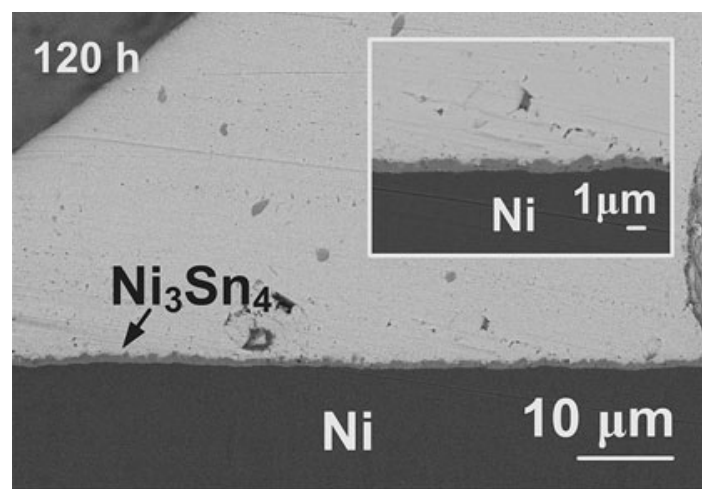

(a)

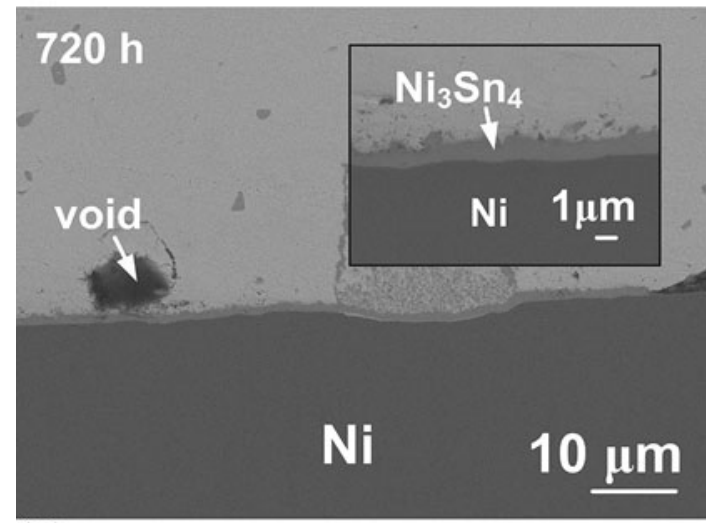

(b)

Fig. 8. SEM micrographs of $\mathrm{Bi}-2 \mathrm{wt} . \% \mathrm{Sn} / \mathrm{Au} / \mathrm{Ni}$ interfaces reacted at $120^{\circ} \mathrm{C}$ for (a) $120 \mathrm{~h}$ and (b) $720 \mathrm{~h}$.

compound grew thicker to about $4.3 \mu \mathrm{m}$ after $90 \mathrm{~min}$, as seen in Fig. 3d, and it was identified as the $\mathrm{Ni}_{3} \mathrm{Sn}_{4}$ phase according to the result of compositional analysis (43.7 at.\%Ni-56.3 at.\% Sn). On increasing the $\mathrm{Sn}$ content to $10 \mathrm{wt} . \%$, the amount of gray needle-type Sn-rich phase in the solder also increased, as seen in Fig. 4. The intermetallic compound grew to about $4.8 \mu \mathrm{m}$ after $90 \mathrm{~min}$, as seen in Fig. $4 \mathrm{~d}$, and it was also identified as the $\mathrm{Ni}_{3} \mathrm{Sn}_{4}$ phase. Based on the above results, the type of intermetallic compound formed at the liquid/solid high-Bi alloy/Ni interface varied with the Sn content. When the Sn content was only 2 wt.\%, the Sn supply was limited and the Nirich $\mathrm{Ni}_{3} \mathrm{Sn}_{2}$ phase was formed, as seen in Fig. 2. After longer reaction (90 $\mathrm{min}$ ), the Sn might be exhausted at the interface and $\mathrm{Bi}$ started to react with $\mathrm{Ni}$ to form the NiBi phase there. By contrast, when the Sn content was higher than 5 wt.\%, the Sn-rich $\mathrm{Ni}_{3} \mathrm{Sn}_{4}$ phase was formed at the interface due to sufficient Sn supply.

Figure 5 shows high-Bi/Ni interfaces reacted at $120^{\circ} \mathrm{C}$ for $120 \mathrm{~h}$ and $2400 \mathrm{~h}$, for Sn content in the high-Bi alloy of 2 wt.\%, 5 wt.\%, and 10 wt.\%. It was found that only one intermetallic compound was formed at the interface, being identified as the $\mathrm{Ni}_{3} \mathrm{Sn}_{4}$ phase. The $\mathrm{Ni}_{3} \mathrm{Sn}_{4}$ phase grew very slowly. After reaction for $2400 \mathrm{~h}$, the thickness of the $\mathrm{Ni}_{3} \mathrm{Sn}_{4}$ phase was only $2.2 \mu \mathrm{m}, 3.1 \mu \mathrm{m}$, and $3.8 \mu \mathrm{m}$ for Sn content of $2 \mathrm{wt.} \%, 5 \mathrm{wt} . \%$, and $10 \mathrm{wt} . \%$, respectively. Figure 6 shows the relationship between the $\mathrm{Ni}_{3} \mathrm{Sn}_{4}$ thickness and the square root of reaction time. It was found that the growth of the $\mathrm{Ni}_{3} \mathrm{Sn}_{4}$ phase followed a parabolic law, indicating a diffusion-controlled mechanism. As discussed above, the Ni-rich $\mathrm{Ni}_{3} \mathrm{Sn}_{2}$ phase instead of the Snrich $\mathrm{Ni}_{3} \mathrm{Sn}_{4}$ phase was formed at the Bi-2 wt. $\% \mathrm{Sn} /$ $\mathrm{Ni}$ interface reacted at $300^{\circ} \mathrm{C}$ due to limited $\mathrm{Sn}$ supply. However, the $\mathrm{Sn}$-rich $\mathrm{Ni}_{3} \mathrm{Sn}_{4}$ phase could be formed at $120^{\circ} \mathrm{C}$ even though the Sn content of the Bi-Sn alloy was only 2 wt.\%. The absence of the $\mathrm{Ni}_{3} \mathrm{Sn}_{2}$ phase at the $\mathrm{Bi}-2$ wt. $\% \mathrm{Sn} / \mathrm{Ni}$ interface reacted at $120^{\circ} \mathrm{C}$ was attributed to the fact that the $\mathrm{Ni}_{3} \mathrm{Sn}_{2}$ phase was hardly observed at lower reaction temperatures. ${ }^{15-17}$ Nucleation difficulty of the $\mathrm{Ni}_{3} \mathrm{Sn}_{2}$ phase at lower reaction temperatures is likely to be the cause ${ }^{15}$ Instead, Sn atoms gradually accumulated at the interface, and the $\mathrm{Ni}_{3} \mathrm{Sn}_{4}$ phase was formed as the Sn supply was sufficient for $\mathrm{Ni}_{3} \mathrm{Sn}_{4}$ phase formation. Because the $\mathrm{Sn}$ atoms accumulated at the interface by solid-state diffusion, a slow growth rate of the $\mathrm{Ni}_{3} \mathrm{Sn}_{4}$ phase was observed as mentioned above.

\section{High-Bi/Ni Interfacial Reactions with an Inserted Au Layer}

Figure 7 shows SEM micrographs of Bi-2 wt.\% $\mathrm{Sn} /$ $\mathrm{Au} / \mathrm{Ni}$ interfaces reacted at $300^{\circ} \mathrm{C}$ for $15 \mathrm{~s}$ to $10 \mathrm{~min}$. Similar to the $\mathrm{Bi}-2 \mathrm{wt} . \% \mathrm{Sn} / \mathrm{Ni}$ interface shown in Fig. 2, the intermetallic compound was still very thin after $90 \mathrm{~s}$ of reaction, as seen in Fig. 7b. After $10 \mathrm{~min}$ of reaction, the intermetallic compound grew thicker and exhibited an island-type structure, as seen in Fig. 7c. Compositional analysis by EDX revealed that the intermetallic compound contained 56.4 at.\%Ni-39.4 at.\%Sn-4.2 at.\%Au, being identified as the $\mathrm{Ni}_{3} \mathrm{Sn}_{2}$ phase with minor dissolved $\mathrm{Au}$. No Au layer was present at the interface, indicating that the Au layer had dissolved into the molten Bi-Sn alloy during the liquid/solid reaction and was immediately incorporated into the formation of the $\mathrm{Ni}_{3} \mathrm{Sn}_{2}$ phase. Comparison of Figs. 2 and 7 reveals that insertion of a $0.7-\mu$ m-thick $\mathrm{Au}$ layer had a negligible influence on the high-Bi/Ni interfacial reaction. Figure 8 shows $\mathrm{Bi}-2$ wt. $\% \mathrm{Sn} / \mathrm{Au} / \mathrm{Ni}$ interfaces reacted at $120^{\circ} \mathrm{C}$ for $120 \mathrm{~h}$ and $720 \mathrm{~h}$. Similar to Fig. 5, only the $\mathrm{Ni}_{3} \mathrm{Sn}_{4}$ phase was formed at the interface after the solid-state reaction.

\section{High-Bi/Cu Interfacial Reactions}

In our previous study, ${ }^{14}$ we investigated liquid/ solid high-Bi/Cu interfacial reactions at $300^{\circ} \mathrm{C}$, for Sn concentrations in the high-Bi alloy of $2 \mathrm{wt} . \%$, 5 wt.\%, and 10 wt.\%. Only the $\mathrm{Cu}_{3} \mathrm{Sn}$ phase was formed at the interface, and it detached from the underlying $\mathrm{Cu}$ substrate rapidly. The gap between the detached $\mathrm{Cu}_{3} \mathrm{Sn}$ phase and the $\mathrm{Cu}$ substrate was filled with a $(\mathrm{Bi})$ phase layer. In the present study, we continued to investigate the high- $\mathrm{Bi} / \mathrm{Cu}$ 


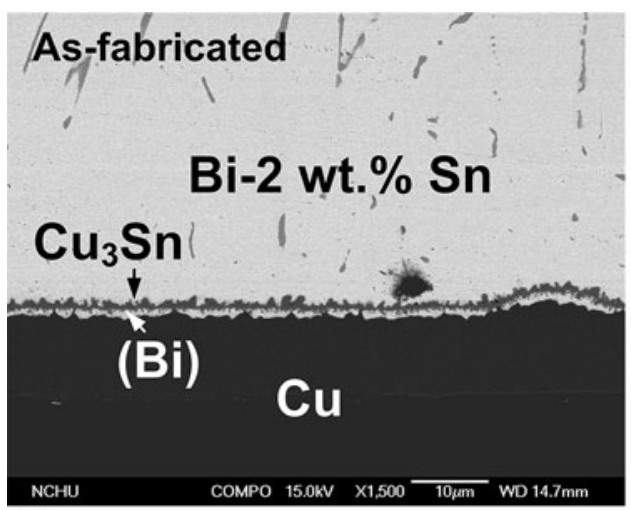

(a)

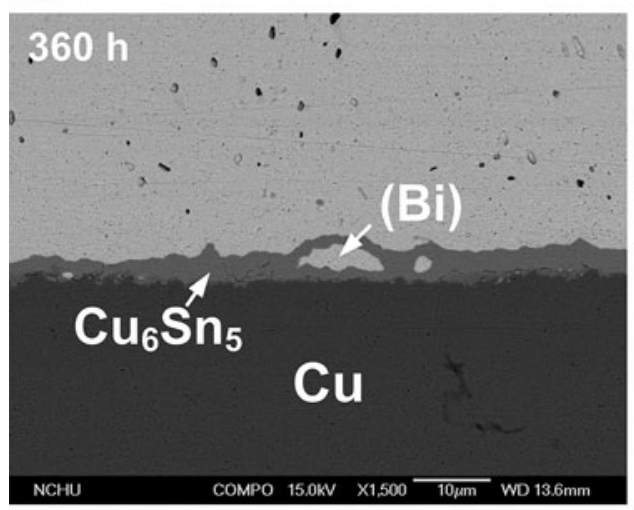

(c)

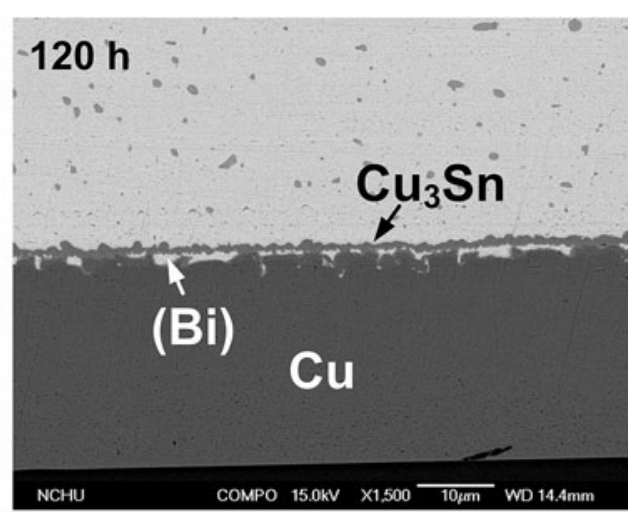

(b)

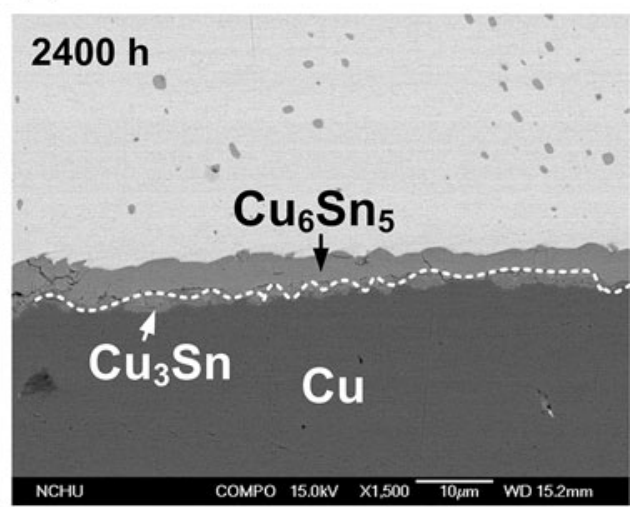

(d)

Fig. 9. SEM micrographs of Bi-2 wt. $\% \mathrm{Sn} / \mathrm{Cu}$ interfaces: (a) as fabricated, and after reaction at $120^{\circ} \mathrm{C}$ for (b) $120 \mathrm{~h}$, (c) $360 \mathrm{~h}$, and (d) $2400 \mathrm{~h}$.

interfacial reaction at a lower temperature of $120^{\circ} \mathrm{C}$, i.e., the solid/solid reaction. The samples used for solid/solid reaction were fabricated by joining the $\mathrm{Bi}-\mathrm{Sn}$ alloys with the $\mathrm{Cu}$ substrates at $300^{\circ} \mathrm{C}$ for $90 \mathrm{~s}$.

Figure 9 shows SEM micrographs of Bi-2 wt.\% $\mathrm{Sn} /$ $\mathrm{Cu}$ interfaces reacted at $120^{\circ} \mathrm{C}$ for various lengths of time. At the as-fabricated $\mathrm{Bi}-2$ wt. $\% \mathrm{Sn} / \mathrm{Cu}$ interface, shown in Fig. 9a, the $\mathrm{Cu}_{3} \mathrm{Sn}$ phase detached from the $\mathrm{Cu}$ substrate and $\mathrm{a}(\mathrm{Bi})$ phase layer was filled in between the $\mathrm{Cu}_{3} \mathrm{Sn}$ phase and the $\mathrm{Cu}$. After solid/ solid reaction, as seen in Fig. 9b-d, two significant changes were observed at the interface and are worthy of discussion. One was the phase transformation from $\mathrm{Cu}_{3} \mathrm{Sn}$ to $\mathrm{Cu}_{6} \mathrm{Sn}_{5}$ with increasing reaction time. The other was that the $(\mathrm{Bi})$ phase layer gradually disappeared and the intermetallic compound reattached to the $\mathrm{Cu}$ substrate. Similar results were found for two other systems, i.e., $\mathrm{Bi}-5$ wt. $\% \mathrm{Sn} / \mathrm{Cu}$ and $\mathrm{Bi}-10$ wt. $\% \mathrm{Sn} / \mathrm{Cu}$, as shown in Figs. 10 and 11. From Fig. 10, we can further understand the mechanism of reattachment of intermetallic compound. In Fig. 10b, most of the $\mathrm{Cu}_{3} \mathrm{Sn}$ phase had reattached to the $\mathrm{Cu}$ substrate, while at some local regions the $\mathrm{Cu}_{3} \mathrm{Sn}$ phase was not directly attached to the $\mathrm{Cu}$ substrate but was separated by a (Bi) phase layer. It was found that a new $\mathrm{Cu}_{3} \mathrm{Sn}$ phase layer, denoted as $\mathrm{Cu}_{3} \mathrm{Sn}$ (lower), formed along the $(\mathrm{Bi}) / \mathrm{Cu}$ interface. To verify the existence of the lower $\mathrm{Cu}_{3} \mathrm{Sn}$ phase, the reaction time was reduced to $72 \mathrm{~h}$; the corresponding crosssectional SEM image of the sample is shown in Fig. 12. In Fig. 12, the (Bi) phase layer is located in between two $\mathrm{Cu}_{3} \mathrm{Sn}$ phase layers. The upper $\mathrm{Cu}_{3} \mathrm{Sn}$ phase layer was formed by liquid/solid reaction at $300^{\circ} \mathrm{C}$, corresponding to the case shown in Fig. 10a, while the lower $\mathrm{Cu}_{3} \mathrm{Sn}$ phase layer was formed by solid/solid reaction at $120^{\circ} \mathrm{C}$. According to the results of compositional analysis, the $(\mathrm{Bi})$ phase layer in Fig. 10 a contained 96.9 at.\%Bi-2.0 at.\%Sn1.1 at.\% Cu. During the solid/solid reaction, the Sn content in the $(\mathrm{Bi})$ phase layer was consumed by reaction with $\mathrm{Cu}$ to form the $\mathrm{Cu}_{3} \mathrm{Sn}$ phase at the $(\mathrm{Bi}) / \mathrm{Cu}$ interface, i.e., the lower $\mathrm{Cu}_{3} \mathrm{Sn}$ phase layer in Fig. 10b. Upon increasing the reaction time to $360 \mathrm{~h}$, two $\mathrm{Cu}_{3} \mathrm{Sn}$ phase layers were simultaneously transformed into the $\mathrm{Cu}_{6} \mathrm{Sn}_{5}$ phase, as seen in Fig. 10c. This was due to sufficient Sn supply from the Bi-Sn alloy after longer solid/solid reaction. In addition, the upper and lower $\mathrm{Cu}_{6} \mathrm{Sn}_{5}$ phase layers mostly contacted with each other, except at some local regions where more $\mathrm{Bi}$ atoms aggregated. Because the growth of the lower $\mathrm{Cu}_{6} \mathrm{Sn}_{5}$ phase reduced the space for the $(\mathrm{Bi})$ phase layer, most of the $\mathrm{Bi}$ atoms were forced to aggregate laterally to some local regions. This local accumulation of $\mathrm{Bi}$ 

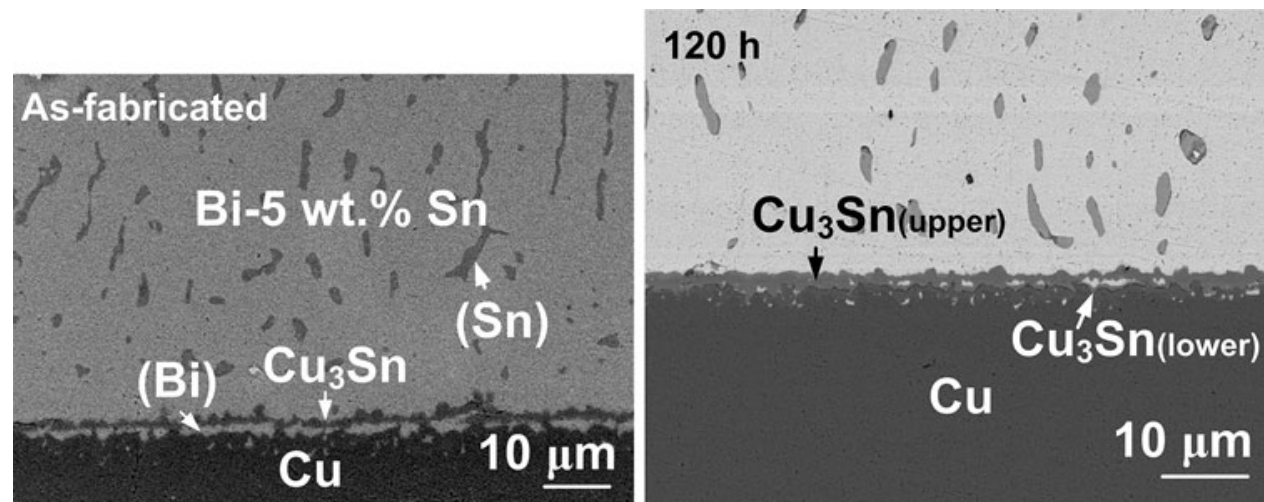

(a)

(b)
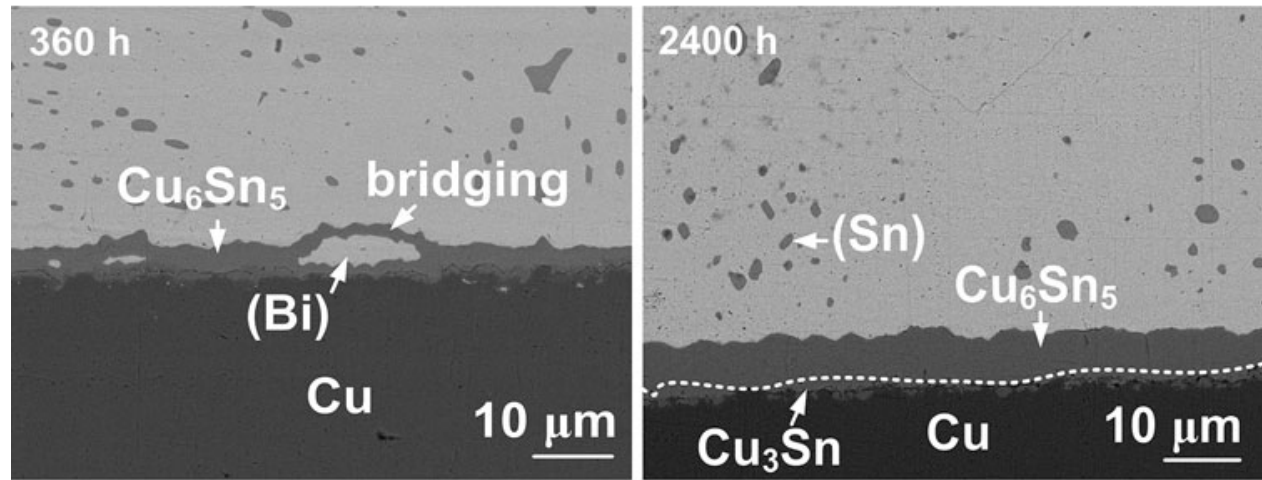

(c)

(d)

Fig. 10. SEM micrographs of Bi-5 wt.\%Sn/Cu interfaces: (a) as fabricated, and after reaction at $120^{\circ} \mathrm{C}$ for (b) $120 \mathrm{~h}$, (c) $360 \mathrm{~h}$, and (d) $2400 \mathrm{~h}$.

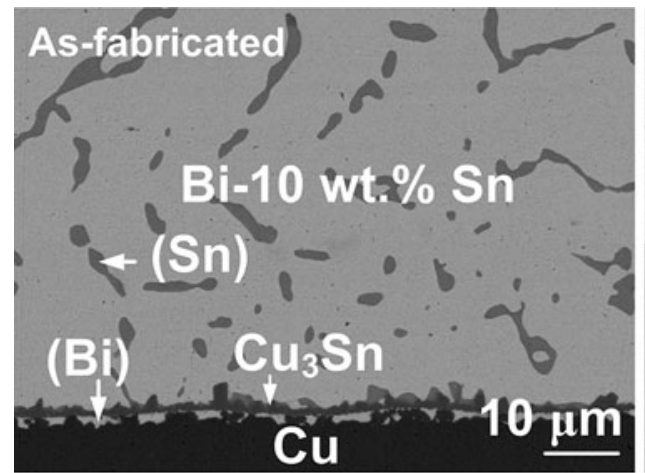

(a)

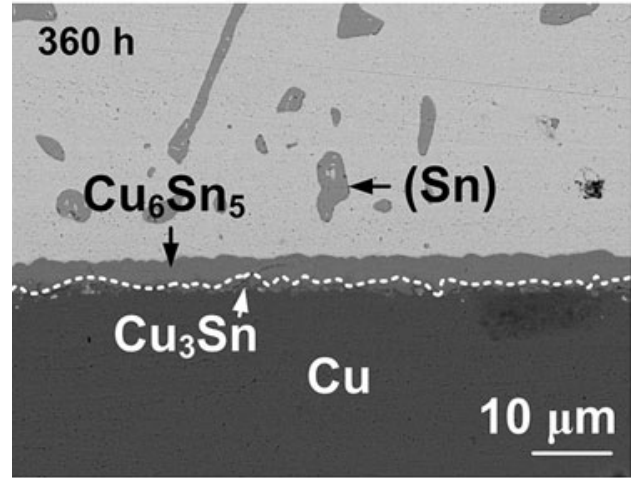

(c)

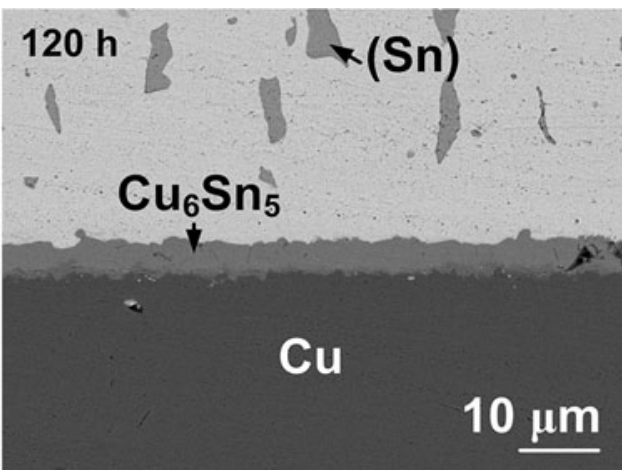

(b)

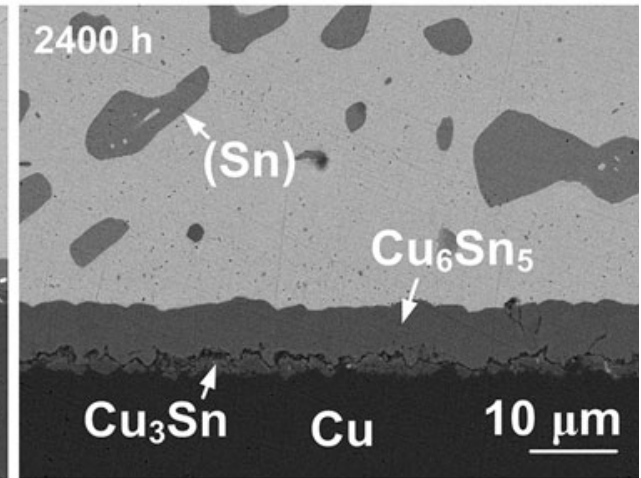

(d)

Fig. 11. SEM micrographs of Bi-10 wt. $\% \mathrm{Sn} / \mathrm{Cu}$ interfaces: (a) as fabricated, and after reaction at $120^{\circ} \mathrm{C}$ for (b) $120 \mathrm{~h}$, (c) $360 \mathrm{~h}$, and (d) $2400 \mathrm{~h}$. 


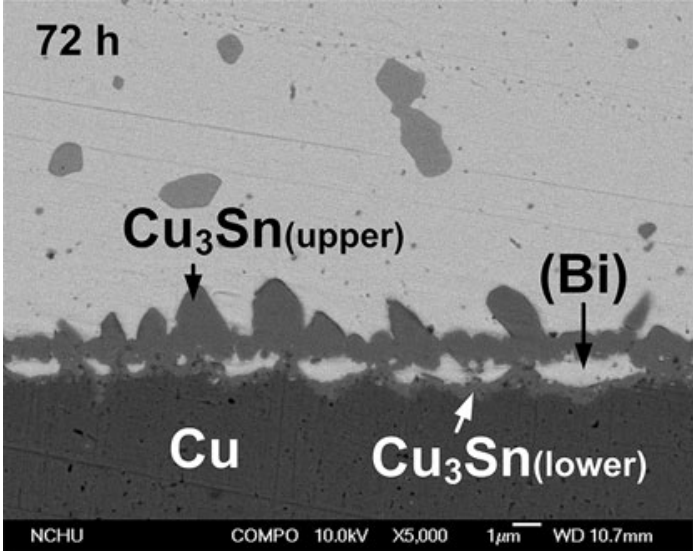

Fig. 12. SEM micrograph of $\mathrm{Bi}-5 \mathrm{wt} . \% \mathrm{Sn} / \mathrm{Cu}$ interface reacted at $120^{\circ} \mathrm{C}$ for $72 \mathrm{~h}$.

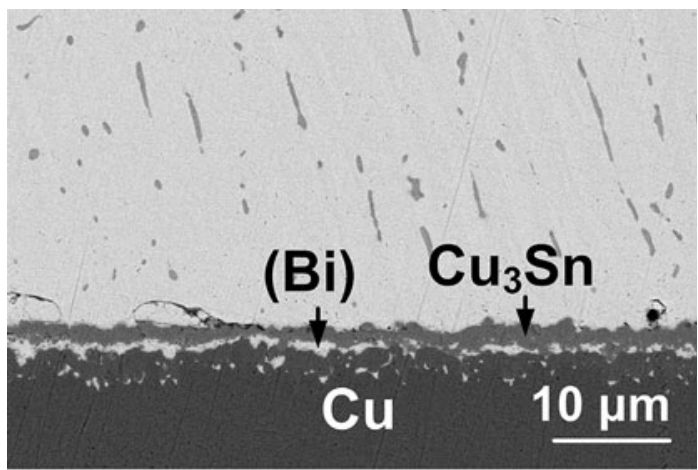

(a)

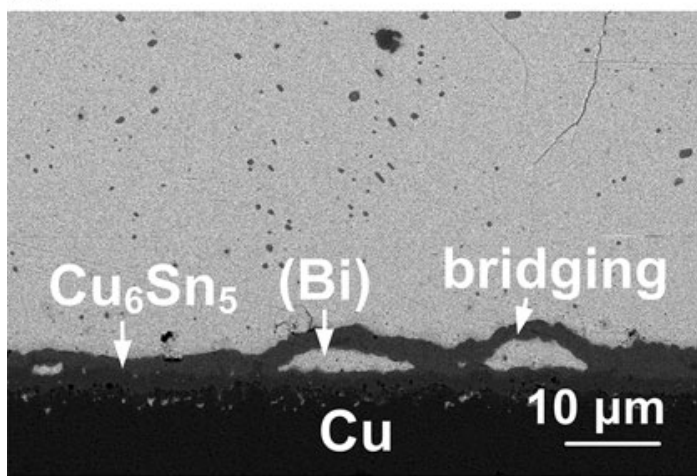

(b)

Fig. 13. SEM micrographs of $\mathrm{Bi}-2 \mathrm{wt} \% \mathrm{Sn} / \mathrm{Cu}$ interfaces after multiple reactions: (a) liquid/solid + solid/solid + liquid/solid and (b) liquid/solid + solid/solid + liquid/solid + solid/solid. The conditions of the liquid/solid and solid/solid reactions are $300^{\circ} \mathrm{C}$ for $90 \mathrm{~s}$ and $120^{\circ} \mathrm{C}$ for $360 \mathrm{~h}$, respectively.

atoms caused the upper $\mathrm{Cu}_{6} \mathrm{Sn}_{5}$ phase layer to bend upward to release the compressive stress, forming an interesting " $\mathrm{Cu}_{6} \mathrm{Sn}_{5}$ bridging" microstructure, as seen in Fig. 10c. After reaction for $2400 \mathrm{~h}$, the $\mathrm{Cu}_{6} \mathrm{Sn}_{5}$ phase was firmly attached to the $\mathrm{Cu}$ substrate and no $(\mathrm{Bi})$ phase was found, as shown in Fig. 10d. A new $\mathrm{Cu}_{3} \mathrm{Sn}$ phase began to form at the $\mathrm{Cu}_{6} \mathrm{Sn}_{5} / \mathrm{Cu}$ interface. Because the $\mathrm{Cu}_{6} \mathrm{Sn}_{5}$ and

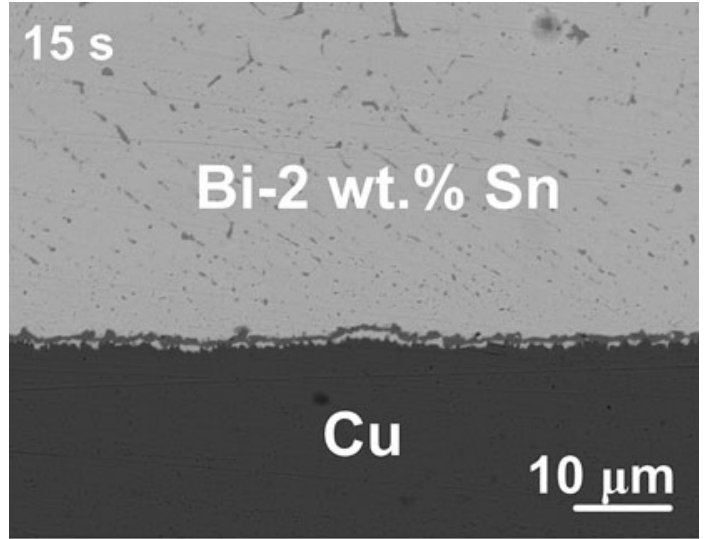

(a)

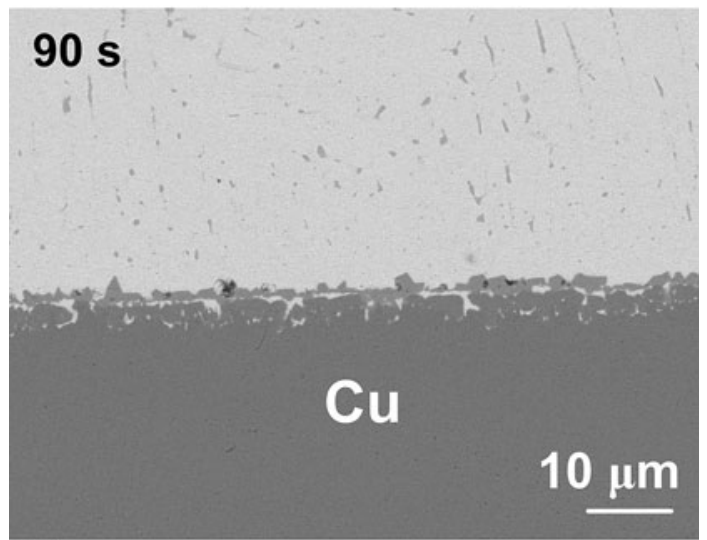

(b)

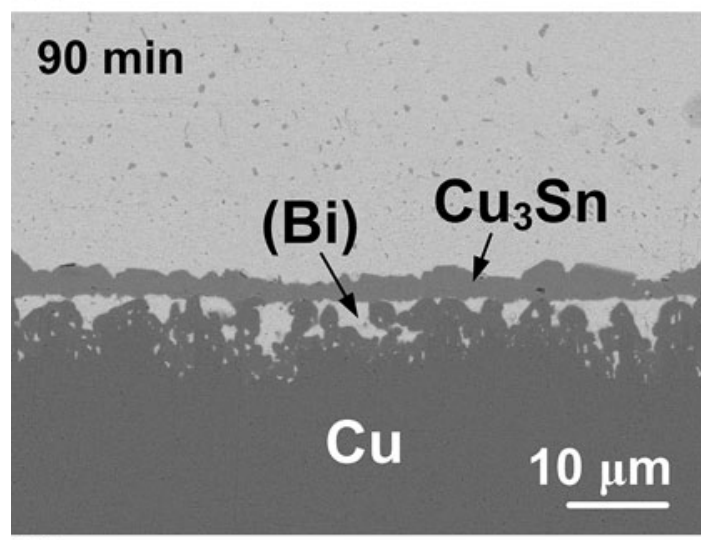

(c)

Fig. 14. SEM micrographs of $\mathrm{Bi}-2 \mathrm{wt} . \% \mathrm{Sn} / \mathrm{Ag} / \mathrm{Cu}$ interfaces reacted at $300^{\circ} \mathrm{C}$ for (a) $15 \mathrm{~s}$, (b) $90 \mathrm{~s}$, and (c) $90 \mathrm{~min}$.

$\mathrm{Cu}_{3} \mathrm{Sn}$ phases contained negligible $\mathrm{Bi}$, the disappearance of the $(\mathrm{Bi})$ phase layer indicates that most of the $\mathrm{Bi}$ atoms returned to the Bi-Sn alloy. However, one question then arises: How did the Bi atoms return to the alloy in the condition that the upper $\mathrm{Cu}_{6} \mathrm{Sn}_{5}$ phase layer acted as a barrier? The real mechanism is still unknown, but a possible one is that the $\mathrm{Bi}$ atoms returned to the alloy by way of grain boundaries in the upper $\mathrm{Cu}_{6} \mathrm{Sn}_{5}$ phase layer. 


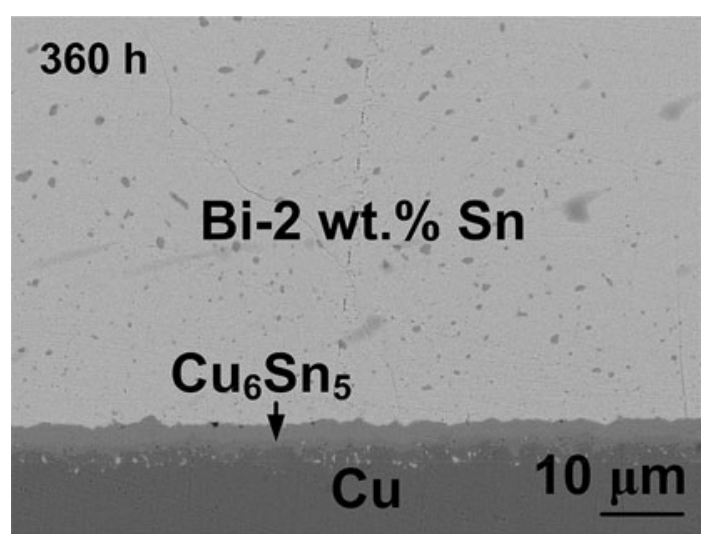

Fig. 15. SEM micrograph of a Bi-2 wt.\%Sn/Ag/Cu interface reacted at $120^{\circ} \mathrm{C}$ for $360 \mathrm{~h}$.

It was also found that, the higher the Sn concentration, the faster the reattachment of the intermetallic compound to the $\mathrm{Cu}$ substrate and the phase transformation. In the $\mathrm{Bi}-10 \mathrm{wt} . \% \mathrm{Sn} / \mathrm{Cu}$ system shown in Fig. $11 \mathrm{~b}$, the $\mathrm{Cu}_{3} \mathrm{Sn}$ phase was transformed into the $\mathrm{Cu}_{6} \mathrm{Sn}_{5}$ phase after $120 \mathrm{~h}$. Simultaneously, the $\mathrm{Cu}_{6} \mathrm{Sn}_{5}$ phase had firmly reattached to the $\mathrm{Cu}$ substrate and no $(\mathrm{Bi})$ phase existed between the $\mathrm{Cu}_{6} \mathrm{Sn}_{5}$ phase and the $\mathrm{Cu}$ substrate.

Figure 13 shows SEM micrographs of Bi$2 \mathrm{wt} . \% \mathrm{Sn} / \mathrm{Cu}$ interfaces after multiple reactions. The reaction condition of the sample shown in Fig. 13a was similar to that in Fig. 9c but with an additional liquid/solid reaction at $300^{\circ} \mathrm{C}$ for $90 \mathrm{~s}$. In Fig. 9c, the $\mathrm{Cu}_{6} \mathrm{Sn}_{5}$ phase had mostly reattached to the $\mathrm{Cu}$ substrate after the solid/solid reaction. However, after the additional liquid/solid reaction, the $\mathrm{Cu}_{6} \mathrm{Sn}_{5}$ phase was transformed into the $\mathrm{Cu}_{3} \mathrm{Sn}$ phase and detached from the $\mathrm{Cu}$ substrate again, as seen in Fig. 13a. The (Bi) phase layer was once again formed in between the detached $\mathrm{Cu}_{3} \mathrm{Sn}$ phase and the $\mathrm{Cu}$ substrate. Apparently, the Bi atoms in the molten state had high mobility and were able to diffuse through the $\mathrm{Cu}_{3} \mathrm{Sn}$ phase layer by way of grain boundaries (or triple junctions) and accumulated at the $\mathrm{Cu}_{3} \mathrm{Sn} / \mathrm{Cu}$ interface to form a continuous (Bi) phase layer. The surface layer of the $\mathrm{Cu}$ substrate was partially dissolved by the molten $(\mathrm{Bi})$ phase, and it looked like the $\mathrm{Cu}_{3} \mathrm{Sn}$ phase detached from the $\mathrm{Cu}$ substrate. When the sample in Fig. 13a was further annealed at $120^{\circ} \mathrm{C}$ for $360 \mathrm{~h}$, the $\mathrm{Cu}_{3} \mathrm{Sn}$ phase was transformed into the $\mathrm{Cu}_{6} \mathrm{Sn}_{5}$ phase again and mostly reattached to the $\mathrm{Cu}$ substrate, except at some local (Bi)-accumulated regions, as seen in Fig. 13b. This microstructural evolution is similar to that in Fig. 9c. It appeared that the microstructural evolution of the high- $\mathrm{Bi} / \mathrm{Cu}$ interface correlated strongly with the reaction condition.

\section{High-Bi/Cu Interfacial Reactions with an Inserted Ag Layer}

Figure 14 shows SEM micrographs of Bi-2 wt. $\% \mathrm{Sn} /$ $\mathrm{Ag} / \mathrm{Cu}$ interfaces reacted at $300^{\circ} \mathrm{C}$ for $15 \mathrm{~s}$ to $90 \mathrm{~min}$.
Similar to our previous results on the $\mathrm{Bi}-2 \mathrm{wt} . \% \mathrm{Sn} /$ $\mathrm{Cu}$ interfacial reaction, ${ }^{14}$ only the $\mathrm{Cu}_{3} \mathrm{Sn}$ phase was formed at the interface, detaching from the underlying $\mathrm{Cu}$ substrate rapidly. The gap between the detached $\mathrm{Cu}_{3} \mathrm{Sn}$ phase and the $\mathrm{Cu}$ substrate was filled with a (Bi) phase layer. No $\mathrm{Ag}$ was observed at the interface. According to the results of compositional analysis, the $\mathrm{Cu}_{3} \mathrm{Sn}$ and $(\mathrm{Bi})$ phase contained 1.3 at.\% and 1.6 at.\% $\mathrm{Ag}$, respectively, indicating that the Ag layer had been consumed and dissolved in the $\mathrm{Cu}_{3} \mathrm{Sn}$ and $(\mathrm{Bi})$ phase during the liquid/solid reaction. Figure 15 shows a $\mathrm{Bi}-2$ wt. $\% \mathrm{Sn} / \mathrm{Ag} / \mathrm{Cu}$ interface reacted at $120^{\circ} \mathrm{C}$ for $360 \mathrm{~h}$. Similar to Fig. 9c, the $\mathrm{Cu}_{3} \mathrm{Sn}$ phase had been transformed into the $\mathrm{Cu}_{6} \mathrm{Sn}_{5}$ phase and reattached to the $\mathrm{Cu}$ substrate.

\section{CONCLUSIONS}

Interfacial reactions between $\mathrm{Bi}-x$ wt.\% $\mathrm{Sn}(x=2$, 5 , and 10) alloys and various substrates $(\mathrm{Ni}, \mathrm{Au} / \mathrm{Ni}$, $\mathrm{Cu}$, and $\mathrm{Ag} / \mathrm{Cu}$ ) were investigated, including liquid/ solid reaction at $300^{\circ} \mathrm{C}$ and solid/solid reaction at $120^{\circ} \mathrm{C}$. In the Bi- $x$ wt. $\% \mathrm{Sn} / \mathrm{Ni}$ interfacial reactions at $300^{\circ} \mathrm{C}$, the type of intermetallic compound formed strongly depended upon the Sn concentration. When the Sn concentration was only 2 wt.\%, the Ni-rich $\mathrm{Ni}_{3} \mathrm{Sn}_{2}$ phase was formed due to limited Sn supply. After longer reaction, $\mathrm{Bi}$ started to react with $\mathrm{Ni}$ to form the $\mathrm{NiBi}$ phase at the $\mathrm{Ni}_{3} \mathrm{Sn}_{2} / \mathrm{Ni}$ interface. When the Sn concentration was higher than $5 \mathrm{wt} . \%$, only the Sn-rich $\mathrm{Ni}_{3} \mathrm{Sn}_{4}$ phase was found. In the $\mathrm{Bi}-x$ wt. $\% \mathrm{Sn} / \mathrm{Ni}$ interfacial reactions at $120^{\circ} \mathrm{C}$, only the $\mathrm{Ni}_{3} \mathrm{Sn}_{4}$ phase was found regardless of the $\mathrm{Sn}$ concentration. The absence of the $\mathrm{Ni}_{3} \mathrm{Sn}_{2}$ phase at the $\mathrm{Bi}-2$ wt.\% $\mathrm{Sn} / \mathrm{Ni}$ interface was ascribed to its nucleation difficulty at lower reaction temperatures. The interfacial reactions between $\mathrm{Bi}-x$ wt.\% $\mathrm{Sn}$ alloy and $\mathrm{Au} / \mathrm{Ni}$ behaved similarly to the $\mathrm{Bi}-x$ wt. $\% \mathrm{Sn} / \mathrm{Ni}$ system.

In the $\mathrm{Bi}-x$ wt. $\% \mathrm{Sn} / \mathrm{Cu}$ interfacial reactions, only the $\mathrm{Cu}_{3} \mathrm{Sn}$ phase was formed at the interface after joining, and it detached from the $\mathrm{Cu}$ substrate. The gap between the detached $\mathrm{Cu}_{3} \mathrm{Sn}$ phase and the $\mathrm{Cu}$ substrate was filled by a $(\mathrm{Bi})$ phase layer. After solid/solid reaction at $120^{\circ} \mathrm{C}$, the $\mathrm{Cu}_{3} \mathrm{Sn}$ phase was gradually transformed into the $\mathrm{Cu}_{6} \mathrm{Sn}_{5}$ phase and reattached back to the $\mathrm{Cu}$ substrate, accompanied by disappearance of the $(\mathrm{Bi})$ phase layer. The rates of phase transformation and interfacial morphological evolution were faster for higher Sn concentration in the Bi-Sn alloy. Insertion of an Ag layer on the $\mathrm{Cu}$ substrate had a negligible effect on the interfacial reactions.

\section{ACKNOWLEDGEMENTS}

The authors gratefully acknowledge the financial support of the National Science Council under Grant NSC 100-2628-E-005-002.

\section{REFERENCES}

1. L.F. Miller, IBM J. Res. Dev. 13, 239 (1969).

2. P.A. Totta and R.P. Sopher, IBM J. Res. Dev. 13, 226 (1969). 
3. K.Z. Wang and C.M. Chen, J. Electron. Mater. 34, 1543 (2005)

4. C.M. Chen, K.Z. Wang, and K.C. Chen, J. Alloy. Compd. 432, 122 (2007).

5. C.P. Lin, C.M. Chen, Y.W. Yen, H.J. Wu, and S.W. Chen, J. Alloy. Compd. 509, 3509 (2011).

6. Y.T. Chen and C.C. Chen, J. Taiwan Inst. Chem. Eng. 43, 295 (2012)

7. P.H. Lee, C.P. Lin, and C.M. Chen, Metall. Mater. Trans. A 44A, 125 (2013).

8. J.M. Song, H.Y. Chuang, and Z.M. Wu, J. Electron. Mater. 35, 1041 (2006).

9. L.N. Lalena, N.F. Dean, and M.W. Weiser, J. Electron. Mater. 31, 1244 (2002).

10. J.M. Song, H.Y. Chuang, Z.M. Wu, and G.W. Lee, J. Taiwan Vac. Soc. 18, 8 (2006).
11. S. Kim, K.S. Kim, S.S. Kim, and K. Suganuma, J. Electron. Mater. 38, 266 (2009).

12. C.H. Wang, H.H. Chen, and P.Y. Li, Mater. Chem. Phys. 136,325 (2012).

13. T.B. Massalski, eds., Binary Alloy Phase Diagrams, Vol. 1 (Materials Park, OH: ASM International, 1990), p. 796.

14. J.Y. Wang, C.F. Lin, and C.M. Chen, J. Electron. Mater. 41, 3303 (2012).

15. S.W. Chen, C.M. Chen, and W.C. Liu, J. Electron. Mater. 27, 1193 (1998).

16. W.K. Liao, C.M. Chen, M.T. Lin, and C.H. Wang, Scripta Mater. 65, 691 (2011)

17. W.J. Tomlinson and H.G. Rhodes, J. Mater. Sci. 22, 1769 (1987). 